fortunes over to it, never waver; in the face of every enemy persist; and then I promise you, young gentlemen, that the future-the future shall speak only German!

German German German German came the reply, the shout-the students standing in their chairs. German German German German. The dignitaries rose and faced us in a line. German, they cried. GERMAN! was our antiphonal response. German . . . GERMAN! German ... GERMAN! Magus Tabor had disappeared-he had not engineered this demonstration for himself-but it was a long time, and a few seats were broken, before we filed out and struggled through the raining streets to soothe our tired throats with beer.

\title{
Against the Grain: Theory and Practice in the Work of William H. Gass
}

The times are full of contradictions. People feel happy and tell you as much, but they are not. Classes are at war, and so are friends and lovers. Families and workplaces are at odds with each other-and with us. Such contradictions, which slip in among the products of our work, have become the subject and the fact of our best fiction-making it complicated, ambivalent, and too often inaccessible. Some of this fiction is written by William H. Gass.

Of course, ever since the novel came to birth amid the contradictions of a rising capitalism, it has been what Lukács, Auerbach, and Goldmann have aptly called the "problematic" genre. It has always contained tensions between realism and romance, mimesis and illusion, type and individual, description and prescription, content and form. But today the situation is intensifying: the novelist is both more cut off from society and more involved in its contradictions. We shouldn't be surprised, therefore, to find in Gass's work a major discrepancy between the theory of his essays and the practice of his fiction-a discrepancy that also makes for difficulty, disturbance, and beauty within the fiction itself. Richard Gilman detected this problem when he wrote that Omensetter's Luck was caught between "ambitions and recalcitrances," "discovery and nostalgia." 1 And Gass himself has warned us 
that he is "one whose views seem stretched like a wet string between passion and detachment, refusal and commitment, tradition and departure."2 I want here to examine some implications of that self-conscious tension as it informs what I take to be the work of a major writer.

Anyone familiar with Gass's essays will have been struck by certain of their shining and upsetting sentences:

There are no descriptions in fiction, there are only constructions, and the principles which govern these constructions are persistently philosophical. (Fiction, p. 17)

It seems a country-headed thing to say: that literature is language, that stories and the places and people in them are merely made of words as chairs are made of smoothed sticks and sometimes of cloth or metal tubes. (Fiction, p. 27)

In our hearts we know what actually surrounds the statue. The same surrounds every other work of art: empty space and silence. (Fiction, p. 49)

Hamlet is a mouth, a vocabulary. (Afterwards, p. 92)

I confess that these sentences are taken out of context and that the contexts "constructed" by Gass sometimes compel us to agree with him. Nevertheless, we squirm more often than we put a check in the margin. Such sentences seem to assume the victory for New Criticism. People with whom we do not agree would applaud them. We blink and look again, but the sentences do not go away. So, for comfort, we turn to the fiction-Omensetter, the stories, the fragments from The Tunnel. John Gardner's common sense seems to support us in this. Of the opinions in Gass's essays, he writes: "They give the reader things to think about while reading Gass's fiction. To think about for half a sentence, before he [or she] gets swept away."3

One explanation of this incongruity in Gass is that maintaining such a theory is a corrective for certain tendencies in his own habits of composition-tendencies toward overwriting or turgidity. To say this sounds as if we are psychologizing (as Gass says we psychologize about Hamlet), but nevertheless, I think we can proceed, remembering that such activities do have their place. Gardner allows that if the "front" of Gass's mind is preoccupied with these formalist theories, the "back" of it "keeps pumping in emotion" when he sits down to his fiction. Gardner definitely accounts for something here, but he also makes it sound as if Gass's writing is automatic, which it most assuredly is not. This confusion is really not Gardner's: his letter is a concise reply to an extended polemic by Gass. Much of the problem results from the easy reduction we make of the standard Freudian terms. The interplay between the conscious and unconscious factors of 
creation is often tactfully and euphemistically placed under a single heading such as "taste" or "talent." Gass himself does this.

Neither keeping the unities nor dissolving them is of any use, nor is loyalty to symmetry, harmony, balance, or coherence. A consistent image can be dull, and an inconsistent one both noble and exciting. You have to taste to tell. (Fiction, p. 241).

In conversation, he is even more candid.

One of the things that you really have to do when you are writing is forget all the crap you've been talking about in theory, because what is important is the work and not your bloody theory. The theory is a protective device. . . . Although you may be interested in talking about work and developing some kind of theory, that is a separate interest, and a very suspicious one. As soon as you get caught up and start writing to a program, you have got to constantly sort of feel the work and experience the taste at the same time. You worry whether you are coming or going. (Advocate interview, p. 12)

But this second statement is also hyperbolic. Gass's theory is more than "crap" or a mere "protective device." It is an integral part of his world view and his creative process. There is a sense in which his theory is his conscience, if not his consciousness. Useful, appropriate and necessary in certain ways, it is not however sufficient. Exactly because it is insufficient Gass must resort to the elusive idea of "taste." Similarly, New Criticism teaches us how to read, but not how to criticize or live. Of Gass's theory (that nothing exists except what's on the page, and, thus, that a character is only words or noises, a vocabulary), Gardner admits that it contains some truth "or Gass wouldn't have said it." But, Gardner continues, fiction is more than its theory and more than its words, for fortunately we fill in with details, employing "empathy, a philosophically mysterious process." Consciousness focuses, but the whole world (a material totality) continues to exist and though we focus on the part, we are aware of the whole. Or, in reference to fiction, the sum of the metaphors is more than their total. Gardner emphasizes the element of synecdoche which is ever-present in the procss of language. Gass, whose Ph.D. thesis was entitled "A Philosophical Investigation of Metaphor," does not overlook this element. Elsewhere, we find him sounding quite a lot like Gardner:

But metaphor is more than a process of inference; it is also a form of presentation or display. (Fiction, p. 63) 
A metaphorical system can itself be interpreted metaphorically, and that one again in terms of another, and another, on and on until positive wonders have been constructed. A simple scene, a sudden flash, can be used metaphorically, to represent a whole-and there are simply a million possibilities. (Afterwords, p. 94)

What Gass does not acknowledge is that this chain reaction set off by the "sudden flash" does not slow down for language and its meanings. Psychologically, the process is called symbolization. Gass denies that there are any images when he reads, claiming that it's "just words" (Advocate interview, p. 10). Elsewhere, however, in his laudatory review of William Thompson's study of the role of imagination in the Easter Rebellion, he agrees with this epigram on epistemology by Thompson: "The consequences of an event take place in the mind, and the mind holds on best to images" (Fiction, p. 267). Reading also is an event. There is a conflict here between Gass's usual emphasis on words and meanings, and the layman's terms for symbolization, this rendering of a "simple scene" with its "million possibilities." Such terms refer often to image-making-the "theater of the mind" or the "mind's eye."

"Represent a whole"-strange talk from one whose theory is ostensibly not representational or mimetic. What Gass reminds himself about here (and what Gardner is reminding Gass about) is that truth resides in both camps, or rather, in the interaction between them. Philosophically (and we must remember that Gass is a philosopher), this interaction has led to the amalgam of abstract, speculative idealism and vulgar, deterministic materialism that Marx developed into dialectical materialism. Aesthetically, most of this interaction has yet to be systematized, but it has led to Brecht's practical discovery that illusion is needed in order to truly and critically represent. In criticism, it may have led to Lucien Goldmann's combination of formalism and socio-historical analysis. The contradictions of our society to which I alluded at the outset are not unconnected to the split between the theory and practice of so much fiction.

Writers are seldom recognized as empiricists, idealists, skeptics, or stoics, though they ought-I mean, now, in terms of the principles of their constructions, for Sartre is everywhere recognized as an existentialist leaning left, but few have noticed that the construction of his novels is utterly bourgeois. (Fiction, pp. 25-26)

Gass is everywhere recognized as a theoretician leaning toward formalism, but the construction of his novels is realist.

I bring this up in this way because the play between Gass's theory and 
his fiction has its social aspect. As Robert Kiley expresses it, "Mr. Gass is not a fastidious esthete or a doctrinal fanatic. He is a moderate man-an artist-pressed to extremes by circumstances." 4 But what are the circumstances? They involve the competition which the novel faces from television, movies, cassettes, and other media, and the consequent degradation of people and their culture which this seems to signal. For Gass, the threat lies also in a certain kind of novel-those books which "trade in slogan and clichés, fads and whims, the slippery and easy, the smart and the latest" (Afterwords, pp. 90-91). The circumstances have called forth best-selling novels on murder in Kansas, anthroposophy, life in the suburbs, "the negro question, the drug question, the jewish question, the catholic question" (Afterwords, p. 91). Gass's particularly acerbic reviews of Updike and Roth show where he stands on fashion, "relevance" and popularity. He is driven to the position of equating realism with journalism and pornography. His avoidance of the topical leads him to deny subject matter and content almost completely, dismissing them as "just a way of organizing" (Advocate interview, p. 16).

On the New York literary market, he is equally trenchant: "When I go to New York City, I feel I'm going to the provinces. What is sophisticated about literary New York? How much of importance goes on there? It is filled with commercial hacks and their pimps." (Falcon interview, p. 43.) Presented with these circumstances, Gass constructs his elaborate defense of poesy. His defense, however, is ultimately of the people for whom the work of art can be an aid-society, reader, artist.

The aim of the artist ought to be to bring into the world objects which do not already exist there, and objects which are especially worthy of love. ... he [or she, i.e., the artist] is valuable to society if what he produces is valuable to it. (Fiction, pp. 284-285)

Confusion arises because value is so hard to measure. The measures of the market (popularity, relevance, marketability) infect even the "purest" art. Thus, in trying to create a worthy addition to reality, Gass counters with the stringent criteria of his formalist theory. Sounding like an aesthete, his position is, however, not one of retreat. He is polemical, awesomely devoted and very hard working. ${ }^{5}$ We have seen the situation before. Ernst Fischer has described the progressive element in this kind of contradictory stance.

L'art pour lart-the attitude adopted by that great and fundamentally realistic poet, Baudelaire-is also a protest against the vulgar utilitarianism, the dreary business preoccupations of the bourgeoisie. It arose 
from the artist's determination not to produce commodities in a world where everything becomes a saleable commodity. ${ }^{6}$

Socially, the first consequence of such a position is the ambivalent relationship one then has with one's readers. Where are they to be found when you don't want them to buy the book, when you don't want the book to be popular and therefore consumed? The object may be worthy of love, but love itself is difficult-"love (someone save the word, I am unable)" ("We have not," p. 30). Thus, we find Gass at one point asking fictional theory to take up the question of "the recreative power of the skillful reader" (Fiction, p. 25) and at another admitting that he has "little patience with the 'creative reader'" (Falcon interview, p. 37). The difference between these two kinds of readers (and the kinds of writers that appeal to them) is a fine one, and one that both writer and reader must constantly struggle to distinguish. "Often these things are matters of a little more or a little less" (Fiction, p. 75). To look at it another way, the distinction has to do with whether the "books act on us" and make us "too much a passive term" (as Gass suggests is sometimes the case with the work of Beckett, Borges and Barth [Fiction, pp. 73-74]), or whether, in the phrase by Arnold Bennett that Gass is so fond of quoting, the books "test us." The classic, the book that tests us, first of all gives us an "invitation." Then, with its figurative system, it "achieves ... the reader's ardent whole participation" in both art and life. It neither toys with us nor asks us to toy with it, but rather calls for rethinking and real changes. The difference is between being challenged and being ordered. It is at this point that Gass quotes Rilke's famous line on the conclusion of such an ardent, artistic process: "You must change your life" (Fiction, p. 76). We might supplement this only with a quote from Mary Wollstonecraft: "Labor to reform thyself to reform the World."7

In searching for the way in which the novel might make a difference, Gass comes to the conclusion that the writing and reading of novels should be like teaching (or testing) and like loving. The writer's relationship to the reader then, if it is good, is full and reciprocal, proceeding dialectically, illuminating both the subject and the participants. Such a process can only be long and difficult, full of scrutiny, commitment and caring. This is a Romantic and romantic notion.

Listen, Furber said, when I was a little boy and learning letters-A . . . B ... C . . . love was never taught to me, I couldn't spell it, the $O$ was always missing, or the $\mathrm{V}$, so I wrote love like live, or lure, or late, or law, or liar. (Omensetter, p. 298)

Much study and hard work are needed to avoid the games and lies that 
prohibit real learning and loving. "We live, most of us, amidst lies, deceits, and confusions. A work of art may not utter the truth, but it must be honest." (Fiction, p. 282.) It is little wonder then that it was so long before Omensetter's Luck was ventured forth as an invitation, metaphorical system and test. We always doubt that we are worthy of love or able to teach. Trust comes hard. "Unfortunately this book was not written to have readers. It was written to not have readers, while still deserving them." (Afterwords, p. 105.)

This problem of audience is, as I mentioned, a social problem. Yet, as Kohler discovers in The Tunnel, the personal life is also social and a part of history. To be denied an audience when one is deserving is a problem to which we correctly grant a certain magnitude, but just as excruciating is the fact that the same set of contradictions alienates each of us from our self. Thus, in "The Artist and Society," we find this schizophrenic slip: "Naturally the artist is an enemy of the state. . . . As a man he may long for action; he may feel injustice like a burn; and certainly he may speak out" (Fiction, p. 287). Riddle, possible story for Borges: when is a writer not a person? Possible answers: when the writer is writing, acting or speaking out. But elsewhere, in reference to Valéry and Wittgenstein, Gass presents philosophy and poetry as activities "where every word allowed to remain in a line represented a series of acts of the poet, or proposals and withdrawals which, in agony, at last, issued in this one, and how no one word was final, how the work was never over, never done, but only, in grief, abandoned as it sometimes had to be ..." (Fiction, p. 249). Because the situation is not static and no one solution will hold, the emphasis, over time, is less on the individual answer than on the continual struggle to answer. Again, Gass tries to move beyond the topical to the truly lasting and exemplary work. Unity, stamina and courage are sought beyond mere impressions and effects. This is true for both life and art. With Coleridge, Gass can settle for nothing less than "what we-what each of us-should somehow be: a complete particular man [or woman]" (Willie Masters'). This must be the concern because "nonpersons unperson persons. They kill. For them no one is human." (Fiction, p. 283)

The stakes, we can see, are high. When writing is an activity and a raison d'etre, ethics and aesthetics merge. When the ethical and political concern is this strong, everything, or almost everything, hinges on every word. To be exemplary is to write exemplary fictions. ${ }^{8}$ Gass quotes Karl Kraus to make this point: "I cannot get myself to accept that a whole sentence can ever come from half a man [or woman]" (Fiction, p. 252). The implications of such a statement can be paralyzing. Agraphia becomes a real hazard. Certain names group themselves around Gass, and we can only worry. Coleridge is often characterized as having possessed the largest unfulfilled potential in English literature. Wittgenstein and Valéry both experienced 
long silences. With Lowry, some similarities become especially haunting. ${ }^{9}$ Both the Volcano and Omensetter were ten years in the making. Lowry's manuscript was burned, Gass's stolen. One can be pitted against one's self, so that nothing gets written, let alone published. "Writing. Not writing. Twin terrors." ("The Doomed," p. 4.) Thus, it is reassuring to welcome each new essay or piece of The Tunnel. A healthy difference between Gass and these others starts to become clear as we watch him observing Valéry, for after devoting a score of his life only to precise, formalistic and quasi-mathematical theories of aesthetics, Valéry could finally return to poetry,

working-in the phrase of Huysmans, one novelist he allowed himself to admire-always au rebours against the grain, and correcting in himself a severe and weakening lean in the direction of the mystical and romantic. ("Valéry: Crisis," p. 16)

Then, in conversation, almost as if it is his secret, the key to his ability to produce, Gass admits, "I'm basically a romantic. I'm a romantic writer and a formalist in theory. So, working against the grain all the time in this way, I try to get something that will stand straight up." (Advocate interview, p. 13.) Romantic (realist?) and formalist-this also is a relationship which is full and reciprocal, and proceeding dialectically.

That Gass's work is proceeding is what is so encouraging. With the realization that it is on-going we can return to the fiction, ready to start through it again and have the next set of a "million possibilities" flash up before us. Going back, for instance, to the opening of the fabulous section on graffiti in "The Clairvoyant" (1964), we see that even then, Gass was working against the grain:

I am an inveterate pencil carver and I consequently understand the qualities of wood. I know how, for instance, the grain will cause the most determined line to quake and wiggle. My first attempt to engrave the letter $c$ in the Covenant plank left a very bent and shaken $l$, though you would never guess it now, the original is so overlaid with flourishes. The secret is to proceed by a series of gentle scratches, repeated often; never an impatient deep gouge which the wood will surely put a crick in, but always the patiently light scratch. ("Clairvoyant," pp. 64-65)

For Gass, so deeply concerned with writing as a form and as a figure of life, it now seems inevitable that he would have taken on the immense metafictional project of which "The Clairvoyant" and Willie Masters' were to have been parts. ${ }^{10}$ 
The Pedersen Kid was conceived under the influence of Gertrude Stein as an exercise in small units, "patiently light scratches." It is more than a formal exercise, however, for in Gass, content and form are always one and the same, as Wittgenstein said ethics and aesthetics are. Or, to phrase it in a more Coleridgean way, form and content must be fused in imagination. Thus, on the level of theme or content, The Pedersen Kid is about Jorge's battle to stay in touch with himself and to love others. Wrapped in the blizzard and separated from his family by distrust, Jorge is driven in on himself until the very end when, finally, after a series of catastrophes, he is "warm inside and out, burning up inside and out, with joy" (Heart, p. 79). His joy, however, is ironically and dramatically undermined by the story's violence. Jorge's final encompassing of the "inside and out" (that previously disorienting fluctuation between solipsism and selflessness) is in some ways analogous to the final position of the writer who after a series of acts, proposals and withdrawals, finally, in joy and grief, abandons himself to one statement. The gentle, repetitious prose of The Pedersen Kid exemplifies such a series of acts.

Gass did not rest, of course, with the small units of The Pedersen Kid. Since that story's simple understated sentences, he has turned increasingly to rhetoric. The change has been so thorough at times one might even say the "original is overlaid with flourishes," or as Mary Ellmann has put it, there is in Gass's work a "contrary allegiance to extravagance . . . a deliberate rhetorical swinging-out beyond previous bounds." 11 There are dangerous tendencies toward histrionics in such projects, but in spite of the risks, Gass has extended and accelerated his use of figurative language in order to range more easily through moods, voices, and dramatic situations. While Gass's metaphors alternate beautifully between the sensuous and the witty, Jethro Furber, his fictional embodiment of rhetoric (Afterwords, p. 96) struggles with isolation, desire, power and jealousy on his way to his confrontation with Omensetter. Within the story, Furber experiences the dangers of rhetoric. Once, he had felt that "yes, words were superior; they maintained a superior control; they touched without your touching; they were at once the bait, the hook, the line, the pole, and the water in between" (Omensetter, p. 138). Then, the rhetoric sours into lies and "all his speeches" become "beautiful barriers of words" (Omensetter, p. 231). He cracks up.

Furber's experience demonstrates to us the problems inherent in rhetorical language. Linguistically, figurative language is a language of relationships, correspondences and levels of meaning. Psychologically, as in Furber's case, it is a language of highs and lows, the epiphanies in the garden with Pike's stone as well as the final confused fall. Throughout Gass's work the reasons for the rhetoric have had first of all to do with the levels of 
meaning it allows to operate simultaneously. The French structuralist Gérard Gennette has described this phenomenon quite succinctly.

Every figure is translatable, and carries its translation, visible in its transparence, like a watermark or palimpsest, under its apparent text. Rhetoric is tied to this duplicity of language. ${ }^{12}$

Duplicity-doubleness, something more than simply one, or deceit.

In The Tunnel, multiplicity is the key, as Kohler's rhetoric moves beyond Furber's. In such a book, the themes will have to be more varied and dense in order to handle the rhetoric (or vice versa). In The Tunnel, we also know that these themes will be more explicitly historical and political than they have been before in Gass's work. Politics are apparent in the earlier pieces. The relationship between Henry and Omensetter was one of the lyrical worshipper confronting and being possessed by the myth of grace, but it was also a landlord-tenant relationship. "Icicles" deals with property relationships. ${ }^{13}$ "In the Heart" occasionally tends toward a kind of pastoral anarchism. Tott raised the questions of the historical convincingly enough that Roger Shattuck has claimed ${ }^{14}$ the "moral" of Omensetter is this thought of Tott's:

Imagine growing up in a world where only generals and geniuses, empires and companies, had histories, not your own town or grandfather, house or Samantha-none of the things you'd loved. (Omensetter, p. 27)

In The Tunnel, the other histories will be told, at least figuratively. The fantastic inventories of things and names, the typographical experiments, the flip-flopping puns, the ellipses, the alliteration, the iambic rhythms, the sight rhymes, the dirty limericks and the ironic jumps of Gass's prose will this time be moving Professor Kohler's rhetorical consciousness through a history of "Fascism in all those little places" (Advocate interview, p. 16). The pieces we have seen so far have shown Kohler dealing with the politics of bedrooms, marriages, families, classrooms, academic departments, publishing, childhood, hometowns, and the self.

My customary tone is scholarly. I always move with care. And I've been praised for weight, the substance of my thought. But it's not the way I feel I want to speak now, and I realize (I've come to it as I write) that my subject's far too serious for scholarship, for history, and I must find 
another form before I let what's captive in me out. ("We Have Not," p. 24)

The form is all new for Kohler perhaps, but for Gass it is part of a progression. Form and content-one and the same, and still the same: writing against one's self so as to write well and writing out of one's self toward another.

\section{NOTES}

1 The Confusion of Realms (New York: Random House, 1969), p. 70.

2 Fiction and the Figures of Life (New York: Alfred A. Knopf, 1970), p. xii. Henceforth, all references to Gass's work will be abbreviated and included parenthetically in the text. The reader is directed to the bibliography below.

3 "Correspondence," New American Review 9 (April, 1970), p. 235.

4 Rev. of Fiction, The New York Times Book Review, February 21, 1971, p. 26.

5 See Stanley Elkin's comments on his good friend's work habits and the exercises he performs in practicing sentences in Scott Sanders, "An Interview with Stanley Elkin," Contemporary Literature, XVI, 2 (Spring, 1975), p. 135. 68.

6 The Necessity of Art: A Marxist Approach (Baltimore: Penguin Books, 1964), p.

7 A Vindication of the Rights of Woman (New York: W. W. Norton and Co., 1967).

$8 \mathrm{Gass}$ is not alone here, even among contemporary American writers. See Robert Coover's preface to his "Seven Exemplary Fictions" in Pricksongs and Descants: Fictions (New York: E. P. Dutton, 1969), pp. 76-79.

9 Frederick Busch has examined some of the thematic similarities between Under the Volcano and "In the Heart of the Heart of the Country" in one of the best articles on Gass's work-"But This is What It is Like to Live in Hell: William H. Gass's 'In the Heart of the Heart of the Country," "Modern Fiction Studies, XIX, 1 (Spring, 1973), pp. 97-108.

10 For a beautifully compact article on Gass as one of four writers of metafiction, see Robert Scholes, "Metafiction," The Iowa Review, I, 4 (Fall, 1970); pp. 100-115.

11 Thinking About Women (New York: Harcourt Brace Jovanovich, 1968), p. 173.

12 Figures (Paris: Seuil, 1966), p. 211, as trans. and quoted by Robert Scholes, Structuralism in Literature: An Introduction (New Haven: Yale, 1974), p. 161.

13 See Patricia Kane, "A Point of Law in William Gass's 'Icicles," Notes on Contemporary Literature, I, 2 (March, 1971), pp. 7-8.

14 "Fiction á la Mode," New York Review of Books, VI, 11 (June 23, 1966), p. 25.

\section{BIBLIOGRAPHY}

I. Books by William H. Gass.

Omensetter's Luck. New York: New American Library, 1966. 
In the Heart of the Heart of the Country. New York: Harper and Row, 1968.

Willie Masters' Lonesome Wife. Tri-Quarterly Supplement Number Two. Evanston:

Northwestern Univ. Press, 1968. Rep., New York: Alfred A. Knopf, 1971.

Fiction and the Figures of Life. New York: Alfred A. Knopf, 1970.

II. Published Sections from The Clairvoyant.

"The Clairvoyant." Location, I, 2 (Summer, 1964), 59-66.

"The Sugar Crock." Arts and Literature: An International Quarterly, 9 (Summer, 1966), 158-171.

"I Wish You Wouldn't." Partisan Review, XLII, 3 (1975), 344-360.

III. Published Sections from The Tunnel.

"We Have Not Lived the Right Life." New American Review 5 (April, 1969), 7-32.

"Why Windows Are Important to Me." Tri-Quarterly, 20 (Winter, 1971), 285-307.

"The Cost of Everything." Fiction, I, 3 (1972), 5 p.

IV. Uncollected Reviews and Essays.

An Untitled Tribute to David Segal. The New York Times Book Review, 21 February 1971, 2.

"Marcel Proust at 100." The New York Times Book Review, 11 July 1971, 1-2, 12, 14.

"The Doomed in Their Sinking." The New York Review of Books, XVIII, 9 (May 18, 1972), 3-4.

"Paul Valéry: Crisis and Resolution." The New York Times Book Review, 20 August 1972, 6-7, 14, 16.

"Paul Valéry: The Later Poems and Prose." The New York Times Book Review, 27 August 1972, 6-7, 30.

"Upright Among Staring Fish." Saturday Review of the Arts, I, I (January 6, 1973), 35-36.

“Gertrude Stein, Geographer: I." The New York Review of Books, XX, 7, (May 17, 1973), 5-8.

"Gertrude Stein, Geographer: II." The New York Review of Books, XX, 8, (May 3, 1973), 25-29.

"The Sporting News." The New York Review of Books, XX, 9 (May 31, 1973), 7-8.

Rev. of Wisconsin Death Trip, by Michael Lesy. The New York Times Book Review, 24 June 1973, 7, 18.

"Groping For Trouts: On Metaphor." Salmagundi, 24 (Fall, 1973), 19-33.

"Malcolm Lowry's Inferno." The New York Review of Books, XX, 19 (November 29, 1973), 26-27.

"Malcolm Lowry's Inferno: II." The New York Review of Books, XX, 20 (December 13, 1973), 28-32.

"The Anatomy of Mind." The New York Review of Books, XXII, 6 (April 17, 1975), $3-4,6$.

"The Scientific Psychology of Sigmund Freud." The New York Review of Books, XXII, 7 (May 1, 1975), 24-29.

"The Battered, Triumphant Sage." The New York Review of Books, XXII, 8 (May 15, 1975), 9-12.

V. Interviews.

"Against the Grain: A Conversation with William H. Gass." Conducted by Ned French and David Keyser. Harvard Advocate, CVI, 4 (Winter, 1973), 8-16.

"Fiction Needn't Say Things-It Should Make Them Out of Words: An Interview with William H. Gass." Conducted by Carole Spearin McCauley. The Falcon, 5 (Winter, 1972), 34-45.

VI. Published Letter.

"A Letter to the Editor," in Thomas McCormack, Ed., Afterwards: Novelists on Their Novels. New York: Harper and Row Publishers, 1969, pp. 88-105. 